\title{
Evaluating the quality of the Digital Elevation Models produced from ASTER stereoscopy for topographic mapping in the Brazilian Amazon Region
}

\author{
CLEBER G. DE OLIVEIRA and WALDIR R. PARADELLA
}

Instituto Nacional de Pesquisas Espaciais (INPE), Divisão de Sensoriamento Remoto (DSR), Av. dos Astronautas, 1758

12227-010 São José dos Campos, SP, Brasil

Manuscript received on January 2, 2008; accepted for publication on September 3, 2008;

presented by ALCIDES N. SIAL

\begin{abstract}
Brazilian Amazon is a vast territory rich in natural renewable and non-renewable resources. Due to the adverse environmental condition (rain, cloud, dense vegetation) and difficult access, topographic information is still poor, and when available needs to be up-dated or re-mapped. In this paper, the feasibility of using elevation generated from orbital ASTER stereo-pairs images for topographic mapping was investigated for the mountainous relief in the Serra dos Carajás, Pará. The quality of information derived from these optical images was evaluated regarding field altimetric measurements. Precise topographic field information acquired from Global Positioning System (GPS) was used as Ground Control Points (GCPs) for the modeling of the stereoscopic Digital Elevation Models (DEMs) and as Independent Check Points (ICPs) for the calculation of elevation accuracies. The analysis was performed following two approaches: (1) the use of Root Mean Square Error (RMSE) and (2) calculations of trend analysis and accuracy. The investigation has shown that the altimetric accuracy from ASTER fulfilled the Brazilian Map Accuracy Standards elevation requirements for 1:100,000 A Class. In addition, ASTER can provide up-dated planimetric information that is also necessary for cartographic production. Thus, when the environment condition allows the acquisition of stereo-pairs, the use of ASTER can be considered an alternative for semi-detailed topographic mapping in similar environments of the Brazilian Amazon.
\end{abstract}

Key words: topographic mapping, DEM, ASTER, stereoscopy, Amazon Region.

\section{INTRODUCTION}

Brazilian Amazon, with almost 5,500,000 km², presents, under an apparently homogeneous forest physiognomy, an enormous spatial variability in climate, geology, soils, river systems, plant and animal communities. Due to the adverse environmental condition (rain, cloud, dense vegetation) and difficult access, the usage of remotely sensed optical data for regular airphoto basis coverage is expensive or even not possible. As a consequence, the Brazilian topography is still poorly known, with almost $25 \%$ of the area covered by maps at reconnaissance scale $(1: 250,000$ up to $1: 1,000,000)$. For the remain-

Correspondence to: Cleber Gonzales de Oliveira

E-mail: cleber@ltid.inpe.br der of the region, the cartography at semi-detailed scale $(1: 100,000)$ needs to be up-dated or re-mapped (IBGE 2001).

Digital Elevation Model (DEM) is a primary input for topographic mapping. With the advent of Advanced Spaceborne Thermal Emission and Reflection Radiometer (ASTER) sensor, launched in 1999 on board of Terra platform, the generation of optical DEMs from the visible and near infrared (VNIR) band 3 (nadir and backwards) could be generated using orbital stereoscopy.

First results were published in the literature with a general consensus of the elevation accuracy with ASTER stereo-pairs ranging from $\pm 7 \mathrm{~m}$ to $\pm 15 \mathrm{~m}$ (Toutin 2002, Hirano et al. 2003). With more available data, additional 
results have been presented focusing on the generation of DEMs and its accuracy (ERSDAC 2001, Toutin and Cheng 2001, Cheng and McBean 2002, Toutin 2002, Hirano et al. 2003, Cuartero et al. 2005, Eckert et al. 2005, Fujisada et al. 2005, San and Süzen 2005), on the application of ASTER for analyzing supraglacial lakes (Wessels et al. 2002) and hazard modeling in Mexico (Huggel et al. 2008). A complete review of the usage of ASTER imagery was recently published considering Geosciences application and DEM generation (Toutin 2008).

However, the extrapolation of these results for operational use in the moist tropics such as in the Amazon Region should be taken with caution. Firstly, these previous investigations were mainly concentrated in sites with favorable environmental (low to moderate vegetation cover, well defined ground features within the Remote Sensing (RS) images, etc.) and experimental conditions (ancillary planialtimetric data with high quality and quantity to derive DEMs and test accuracies). Secondly, GCPs with quality, number and distribution is a critical point for the operational use of the technology in the tropics. In this paper, the altimetric quality of DEMs generated with $30 \mathrm{~m}$ from ASTER data was evaluated for a mountainous topographic terrain in the Brazilian Amazon. It is an outgrowth of previous investigations of the authors focusing on the use of orbital stereoscopic to overcome the critical lack of topographic information in the Brazilian Amazon (Paradella et al. 2005).

\section{STUDY SITE}

The test-site located in the Serra dos Carajás, easternmost border of the Brazilian Amazon region, was selected for the investigation (Fig. 1). The Carajás Mineral Province, within the domains of the Amazonia rain forest, is the most important Brazilian mineral province and comprises several mineral deposits, of a diversified variety, particularly with the world's largest iron deposits. The region is characterized by a set of hills and plateaus known as Serra dos Carajás (altitudes from 500 to 900 meters) surrounded by southern and northern lowlands (altitudes around 200 meters), totally covered by Ombrophilous Equatorial forest. The study area comprises part of the Água Fria, Caldeirão, Rio Parauapebas, Rio Verde, Serra dos Carajás and Serra Pelada topographic sheets $(1: 100,000$ scale) produced from black and white airphotos by the Brazilian Institute of Geography and Statistics (IBGE) during the 1979-1981 period.

\section{DATASET}

\section{ASTER STEREO-PAIRS}

ASTER is a multispectral optical imaging system flying aboard satellite TERRA, which was launched in December 1999 as part of NASA's Earth Observing System (EOS). ASTER is comprised of 14 spectral bands under 3 separate sensor subsystems: VNIR, with 3 bands covering the visible and near infrared spectral range $(0.5-1.0 \mu \mathrm{m})$ with $15 \mathrm{~m}$ spatial resolution; SWIR, with 6 bands located in the short-wave infrared spectral range $(1.0-2.5 \mu \mathrm{m})$ with $30 \mathrm{~m}$ resolution and TIR, represented by 5 bands in the thermal infrared spectral range $(8-12 \mu \mathrm{m})$ with $90 \mathrm{~m}$ spatial resolution. As shown in Figure 2, using the VNIR one nadir-looking (3N, 0.76$0.86 \mu \mathrm{m})$ and one backward-looking (3B, 27.7 degrees off-nadir) telescope it is possible to acquire black-andwhite stereo-pairs under an along-track stereo configuration with a base-to-height ratio of 0.6. An approximately $60 \mathrm{~s}$ interval is noted between the time the nadir telescope passes over a ground location and the aft telescope records the same point on the ground track of the satellite. An ASTER scene covers an area of $61.5 \times$ $63 \mathrm{~km}$ and the cross-track pointing out to $136 \mathrm{~km}$ allows viewing of any area on Earth at least once every sixteen days. The along-track mode of data acquisition is considered a major advantage as compare to cross-track since the images forming the stereo-pairs are acquired a few seconds apart under similar environmental and lighting. This favors stereo configuration of consistent quality and well suited for DEM generation by automated stereo-correlation techniques (Hirano et al. 2003, Kamp et al. 2003).

Overall, the ability to extract elevations from ASTER stereopairs using correlation techniques meets expectation (Toutin and Cheng 2001, Toutin 2002, Hirano et al. 2003). ASTER has been acquiring stereodata since March 2000, and so far, no result has been published related to the generation of DEMs in the Amazon Region. Thus, this paper examined the possibilities of creating DEMs and evaluated its elevation accuracy from one ASTER-level 1A raw stereo-pair, which was acquired on August 16, 2001 and fortunately was absolutely cloud-free. 


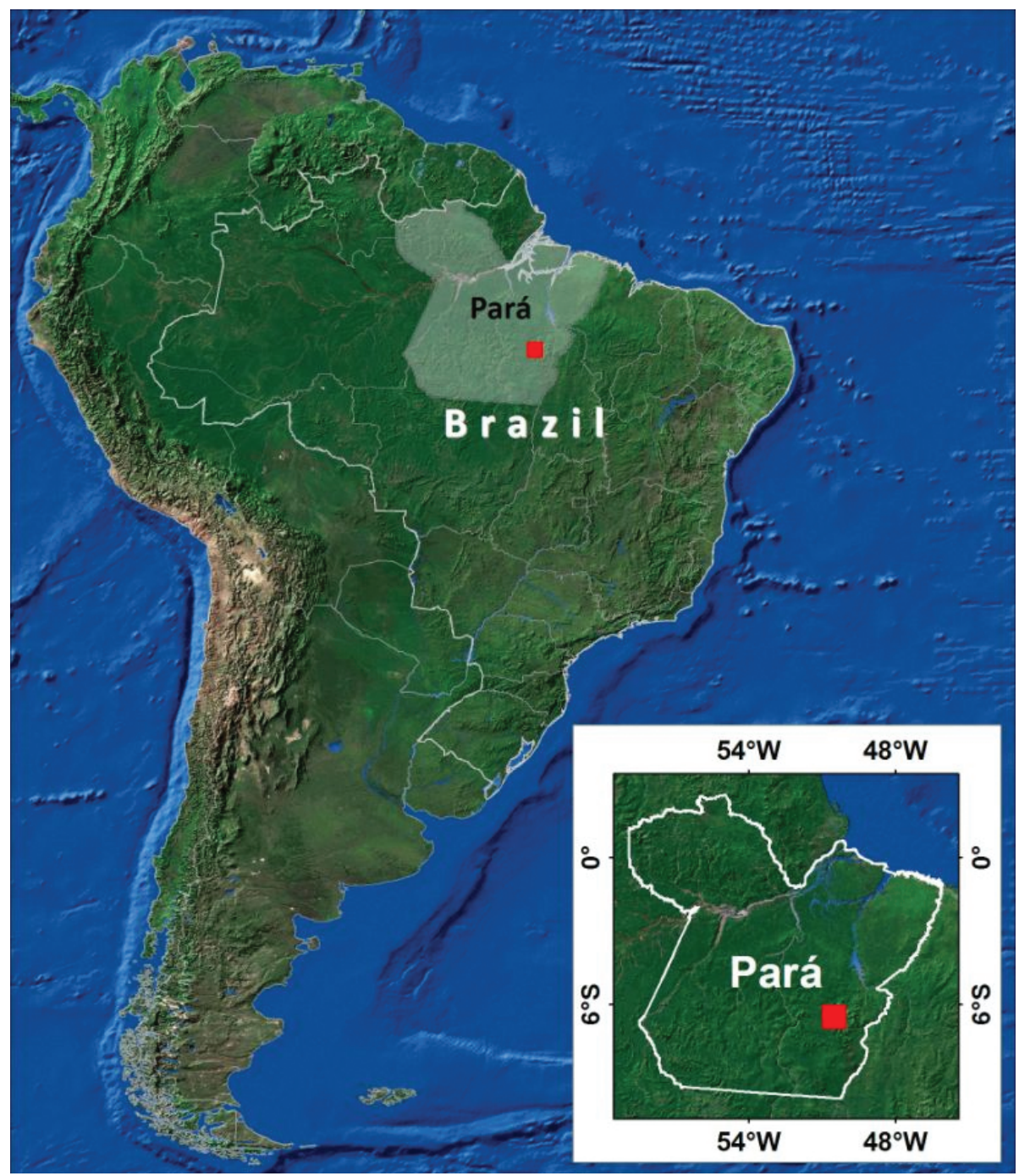

Fig. 1 - Location of the study area in the Pará State.

\section{GPS Field MEASUREMENTS}

Although the requirements for the maximum GCPs number are not specified, a larger number is recommended to improve accuracy for DEM extraction with samples ideally chosen on a variety of locations and ground elevations, at the lowest and highest elevation. On the other hand, ICPs also play a key role in quality control for mapping production. Generally, a balance has to be reached between few ICPs, giving invalid accuracy estimation and an excessive number, providing a safe analysis but with unrealistic cost of acquisition in the field. According to Merchant (1987) a minimum of
20 well-distributed ICPs is necessary within a map. It is important to mention that topographic maps in Brazil should be classified according to the National Map Accuracy Standard (PEC - Padrão de Exatidão Cartográfico in Portuguese), defined by the decree 89,817 of 1984 , which classifies map products in relation to geometric quality. PEC is a statistical indicator (90\% of probability) for planialtimetric accuracy, corresponding to 1.6449 times the Standard Error $(\mathrm{PEC}=1.6449 \times \mathrm{SE})$, and considering equivalent the expressions Standard Error, Standard Deviation Error and RMSE. For a 1:100,000 scale A Class map, the SE corresponds to $16.66 \mathrm{~m} \mathrm{(1/3}$ of the equidistance of contour lines). Precise planial- 


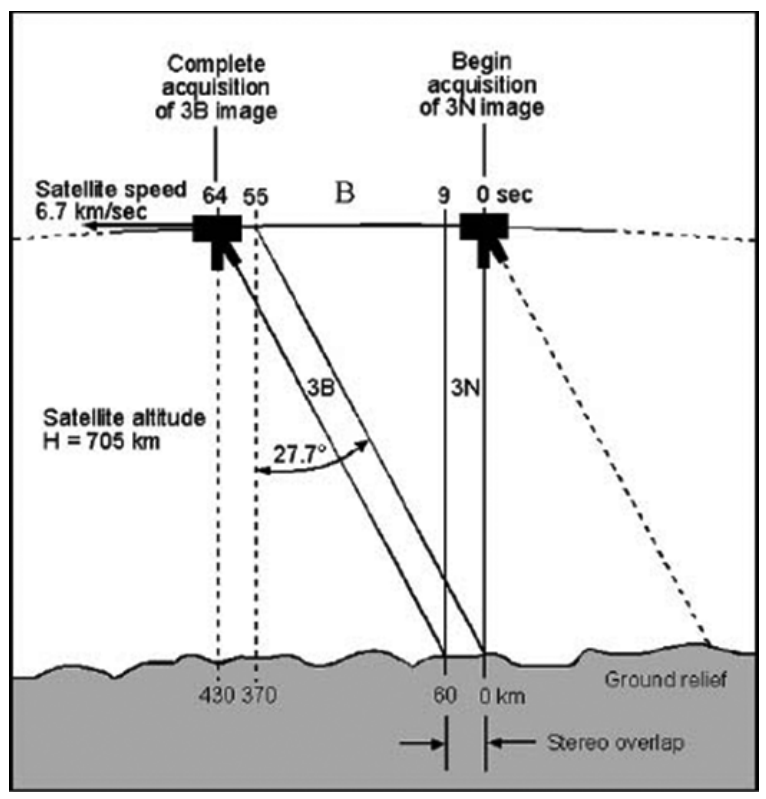

Fig. 2 - ASTER stereo configuration (source: Toutin 2002).

timetric measurements from Global Positioning System (GPS) were acquired in the test-site in September 2002, and used as GCPs for the modeling of the DEMs and as ICPs for the calculation of altimetric accuracies. Two dual frequency receptors were used in the field for static GPS measurements using vehicles and helicopters (Fig. 3). A total of 48 static GPS measurements and 35,000 kinematics GPS measurements were collected. The maximum errors with a probability of $68.3 \%(1 \sigma)$ for the positions estimated were $18 \mathrm{~cm}$ (latitude), $75 \mathrm{~cm}$ (longitude) and $24 \mathrm{~cm}$ (geometric altitude).

\section{MATERIALS AND METHODS}

\section{Generation of Stereoscopic DEM}

The Toutin's model based on OrthoEngine package (PCI Geomatics 2003) was used to compute the stereo model geometry and the 3D intersections for the DEMs generations. The model is based on geometric and stereoscopic models equivalent to the co-linearity and co-planarity equations in photogrammetry, which reflect the physical reality of the complete viewing geometry taking into account the distortions of platform, sensor, Earth, projection. If no GCPs are used, the stereo model is based upon the ancillary data exclusively and a relative DEM is produced (Satellite DEM). It is closer to the average forest height rather than the real topography. The ad- dition of GCPs refines the model and improves on its accuracy and an absolute DEM is generated (GCPs calibrated DEM). Once the geometric model is computed, quasi-epipolar curve images are generated and the elevation parallax is derived based on automated image matching procedure, which utilizes a multiscale area correlation with a mean normalized cross-correlation approach (Cheng and Toutin 1998). For the transformation of geometric into ortometric altitudes, the MAPGEO98 model was used with absolute and relative accuracies of $1.5 \mathrm{~m}$ and $1.0 \mathrm{~cm} / \mathrm{km}$, respectively (Camargo 2003).

\section{Statistical AnALYsis}

The accuracy and classification of the products were estimated by comparison of the DEMs elevation values and the real elevation given by ICPs. The analysis was performed following two approaches: (1) the use of RMSE (and LE90, linear error with 90\% probability, which is normally used in the international literature) for the overall classification of the DEMs considering the PEC limits and, (2) calculations of trend analysis and accuracy based on the methodology proposed by Galo and Camargo (1994), which takes into account computed discrepancies and standard deviations. The aim of trend analysis is to check for the presence of systematic errors and it was based on the hypothesis $\left(H_{0}: \Delta \bar{Z}=0 ; H_{1}: \Delta \bar{Z}\right.$ $\neq 0$ ) whose acceptance or rejection is controlled by the computed Student $\mathrm{t}$ statistics compared with the theoretical $t_{n-1 ; \alpha}$. Accuracy analysis uses comparison of the variance of sample deviations $\left(S_{\Delta x}^{2}\right)$ to their respective pre-defined (table) values. The test is carried out using a hypothesis about the mean and standard deviation of the sample for each of the altimetric value. Chi-square $\left(\chi^{2}\right)$ is the statistical procedure that was applied. The accuracy of the product can be estimated in the $Z$ values using standard statistical methodology involving the comparison of a sample value of $\chi^{2}$ and the table value $\chi_{(n-1, \alpha)}^{2}$. The values of $\chi^{2}$ are calculated based on the equations:

$$
\chi_{Z}^{2}=(n-1) \frac{S_{\Delta Z}^{2}}{\sigma_{Z}^{2}}
$$

where $S_{\Delta Z}$ is obtained from Table I and vary as a function of the map scale using the relation: $\sigma_{Z}=\mathrm{SE}$. The value of the SE for the PEC was already discussed. 


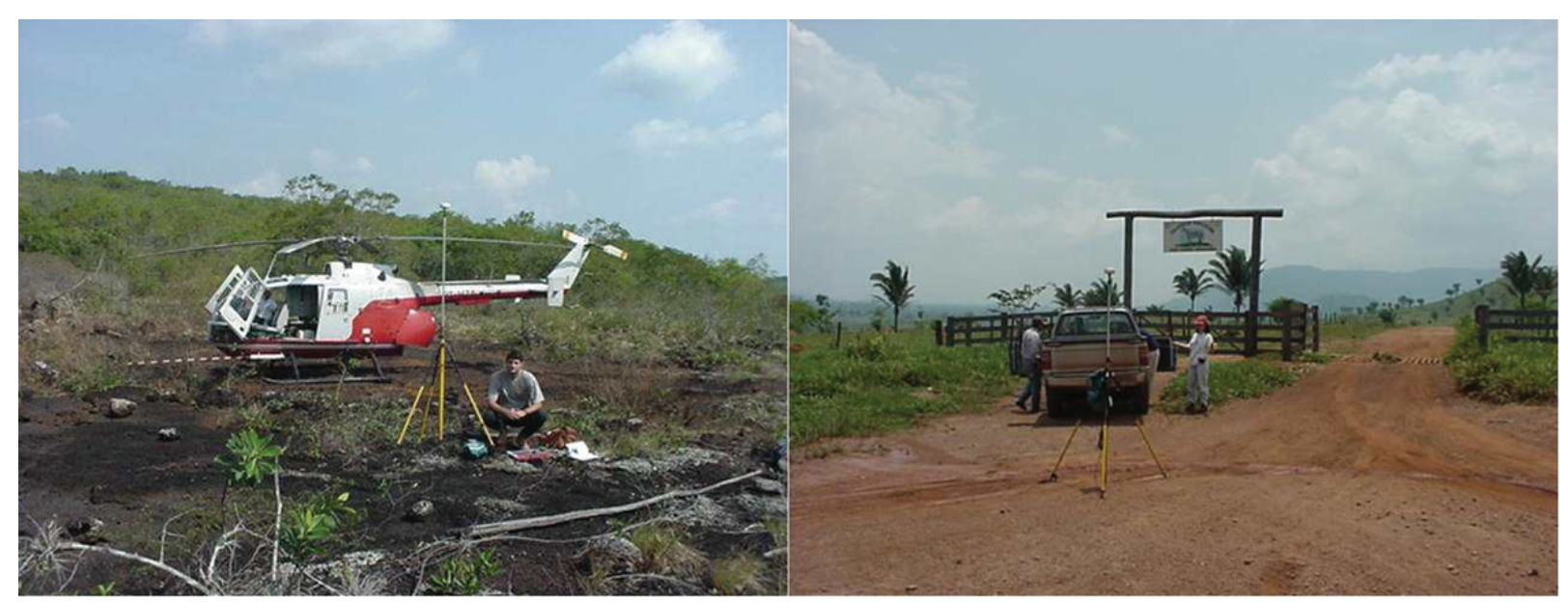

Fig. 3 - Details of the GPS campaign in Carajás.

TABLE I

Results of the GCPs/ICPs combinations $(\Delta \bar{Z}=$ Mean of discrepancies, $\mathbf{S}_{\Delta Z}=$ Standard Deviation and RMSE $=$ Root Mean Square Errors).

\begin{tabular}{|c|c|c|c|c|}
\hline DEMs & GCPs / ICPs & $\begin{array}{l}\Delta \bar{Z} \\
(\mathrm{~m})\end{array}$ & $\begin{array}{c}\mathrm{S}_{\Delta Z} \\
(\mathrm{~m})\end{array}$ & $\begin{array}{c}\text { RMSE } \\
\text { (m) }\end{array}$ \\
\hline 1 & $6 / 42$ & 6.63 & 9.34 & 11.36 \\
\hline 2 & $7 / 41$ & 4.63 & 9.17 & 10.17 \\
\hline 3 & $8 / 40$ & 0.55 & 11.30 & 11.17 \\
\hline 4 & $9 / 39$ & -0.17 & 11.43 & 11.43 \\
\hline 5 & $10 / 38$ & 1.70 & 10.15 & 10.16 \\
\hline 6 & $11 / 37$ & 1.46 & 10.39 & 10.35 \\
\hline 7 & $12 / 36$ & 0.19 & 10.09 & 9.95 \\
\hline 8 & $13 / 35$ & 0.44 & 10.12 & 9.99 \\
\hline 9 & $14 / 34$ & 0.37 & 10.65 & 10.50 \\
\hline 10 & $15 / 33$ & 1.33 & 10.51 & 10.43 \\
\hline 11 & $16 / 32$ & 0.50 & 10.01 & 9.87 \\
\hline 12 & $17 / 31$ & -0.45 & 9.66 & 9.52 \\
\hline 13 & $18 / 30$ & -1.07 & 9.89 & 9.78 \\
\hline 14 & $19 / 29$ & -1.13 & 9.90 & 9.79 \\
\hline 15 & $20 / 28$ & -0.47 & 9.46 & 9.30 \\
\hline 16 & $21 / 27$ & 0.00 & 9.74 & 9.56 \\
\hline 17 & $22 / 26$ & 0.10 & 9.75 & 9.56 \\
\hline 18 & $23 / 25$ & 0.61 & 9.12 & 8.95 \\
\hline 19 & $24 / 24$ & 0.88 & 9.50 & 9.34 \\
\hline 20 & $25 / 23$ & 1.48 & 9.06 & 8.98 \\
\hline 21 & $26 / 22$ & 0.05 & 9.79 & 9.57 \\
\hline 22 & $27 / 21$ & 0.31 & 9.76 & 9.53 \\
\hline 23 & $28 / 20$ & -1.81 & 8.99 & 8.94 \\
\hline
\end{tabular}

\section{RESULTS AND DISCUSSION}

Since the number of GCPs and ICPs has direct influence on the DEM generation and on the estimation of the elevation accuracy, this issue was also investigated. An empirical approach was applied in order to define the minimum GCPs number required to produce a good product. Starting with 6 GCPs and 42 ICPs, additional GCPs points were gradually added with the corresponding DEMs being analyzed regarding quality (presence of failed areas, blunders, etc.) and statistics (residual report errors on GCPs) up to the final combination using 28 GCPs and 20 ICPs for accuracy estimation from the total of 48 GPS available. Table I and Figure 4 present the statistics of the results for all combinations of stereoscopic DEMs.

Taking into account the results of Table I, statistical values related to mean, to the minimum and maximum values of Standard Deviation and to RMSE were further obtained considering all the number of produced DEMs (Table II).

TABLE II

Mean, minimum and maximum values of Standard Deviation and RMSE for all extracted DEMs.

\begin{tabular}{c|c|c}
\hline Values & Standard Deviation $(\mathrm{m})$ & RMSE $(\mathrm{m})$ \\
\hline Minimum & 8.99 & 8.94 \\
\hline Mean & 9.90 & 9.92 \\
\hline Maximum & 11.43 & 11.43 \\
\hline
\end{tabular}




\section{Standard Deviations for ASTER DEMs}

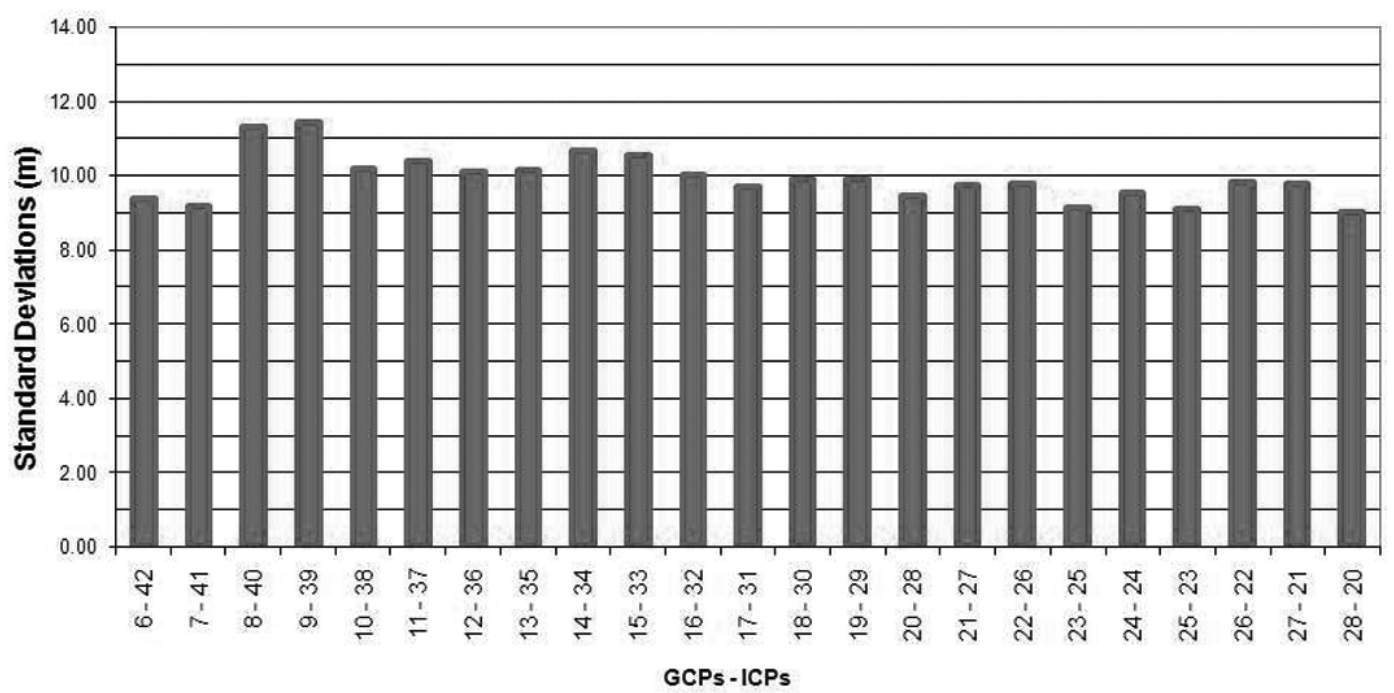

Fig. 4 - Distribution of Standard Deviations for ASTER DEMs considering the influence of the numbers of GCPs and ICPs.

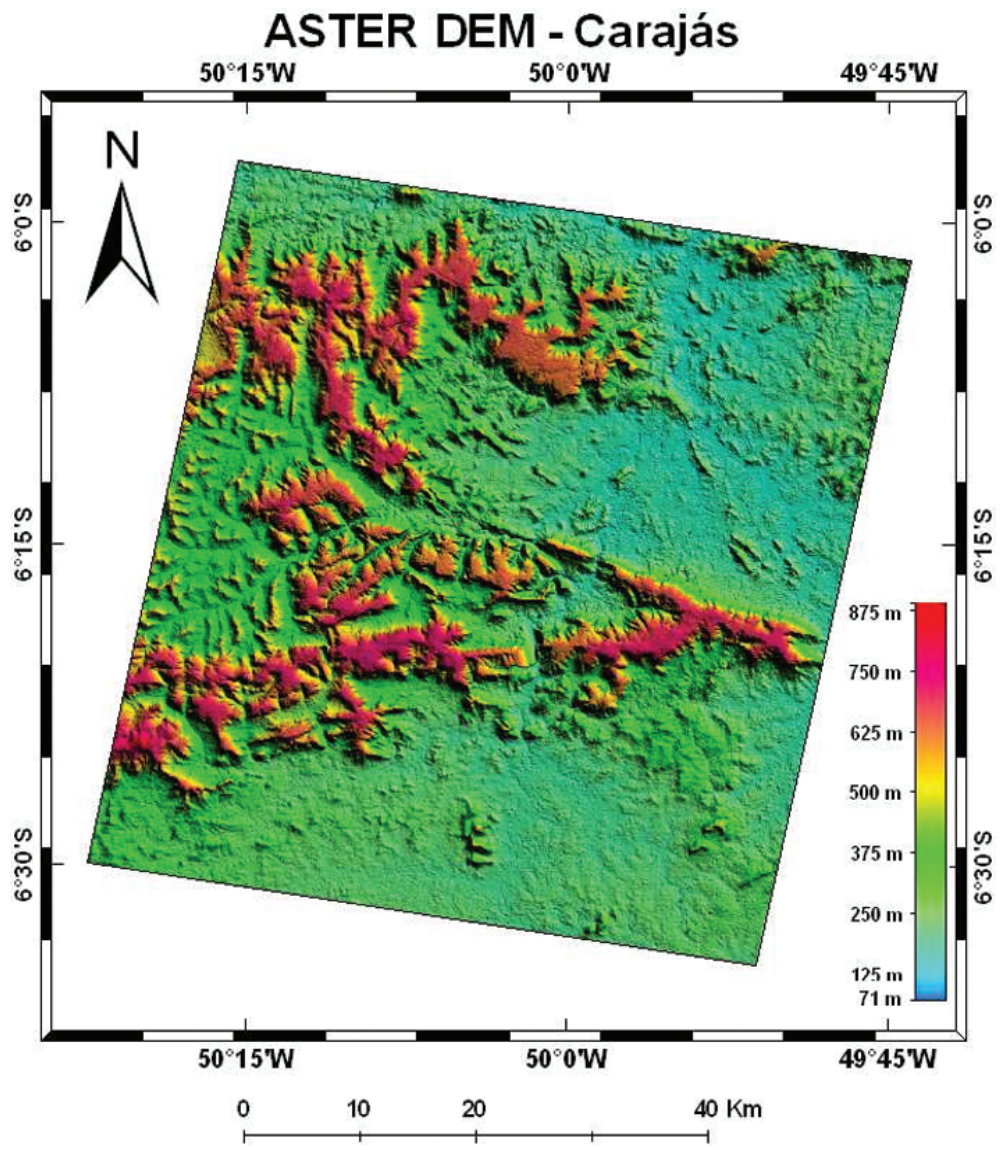

Fig. 5 - Best ASTER DEM using a combination of 28 GCPs and 20 ICPs. 
TABLE III

Statistics for Trend Analysis and Accuracy regarding the 23 DEMs produced from distinct combination of GCPs and ICPs.

\begin{tabular}{|c|c|c|c|c|c|}
\hline DEMs & GCPs / ICPs & $t_{\text {sample }}$ & $t_{(n-1 ; 5 \%)}$ & $\chi_{\text {sample (A Class) }}^{2}$ & $\chi_{(n-1 ; 10 \%)}^{2}$ \\
\hline 1 & $6 / 42$ & 4.600 & 1.683 & 12.881 & 52.949 \\
\hline 2 & $7 / 41$ & 3.234 & 1.684 & 12.108 & 51.805 \\
\hline 3 & $8 / 40$ & 0.308 & 1.685 & 17.924 & 50.660 \\
\hline 4 & $9 / 39$ & 0.095 & 1.686 & 17.878 & 49.513 \\
\hline 5 & $10 / 38$ & 1.033 & 1.687 & 13.718 & 48.363 \\
\hline 6 & $11 / 37$ & 0.857 & 1.688 & 13.987 & 47.212 \\
\hline 7 & $12 / 36$ & 0.113 & 1.690 & 12.835 & 46.059 \\
\hline 8 & $13 / 35$ & 0.259 & 1.691 & 12.543 & 44.903 \\
\hline 9 & $14 / 34$ & 0.200 & 1.692 & 13.473 & 43.745 \\
\hline 10 & $15 / 33$ & 0.726 & 1,694 & 12.725 & 42.585 \\
\hline 11 & $16 / 32$ & 0.281 & 1.696 & 11.184 & 41.422 \\
\hline 12 & $17 / 31$ & 0.259 & 1.697 & 10.088 & 40.256 \\
\hline 13 & $18 / 30$ & 0.595 & 1.699 & 10.202 & 39.087 \\
\hline 14 & $19 / 29$ & 0.617 & 1.701 & 9.873 & 37.916 \\
\hline 15 & $20 / 28$ & 0.264 & 1.703 & 8.689 & 36.741 \\
\hline 16 & $21 / 27$ & 0.002 & 1.706 & 8.877 & 35.563 \\
\hline 17 & $22 / 26$ & 0.051 & 1.708 & 8.547 & 34.382 \\
\hline 18 & $23 / 25$ & 0.332 & 1.711 & 7.182 & 33.196 \\
\hline 19 & $24 / 24$ & 0.452 & 1.714 & 7.479 & 32.007 \\
\hline 20 & $25 / 23$ & 0.781 & 1.717 & 6.501 & 30.813 \\
\hline 21 & $26 / 22$ & 0.025 & 1.721 & 7.253 & 29.615 \\
\hline 22 & $27 / 21$ & 0.147 & 1.725 & 6.859 & 28.412 \\
\hline 23 & $28 / 20$ & 0.901 & 1.729 & 5.523 & 27.204 \\
\hline
\end{tabular}

The conclusion to be drawn from the trend analysis and accuracy (Table III) is that only the ASTER DEMs produced from 6 and 7 GCPs did not fulfill the trend re-

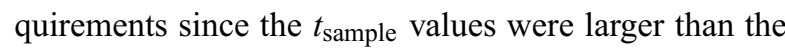
$t_{(n-1,5 \%)}$ values. In addition, the comparison of $\chi_{\text {sample }}^{2}$ and $\chi_{(n-1.10 \%)}^{2}$ values indicated that the DEMs are compatible with the Brazilian PEC elevation requirements for a 1:100,000 A Class Map (RMSE $\leq 16.66 \mathrm{~m}$ ), independently of the number of GCPs that was used as input for the DEMs extraction.

Finally, the investigation also pointed out that the combination of 28 GCPs and 20 ICPs (DEM 23) presented the best performance (Fig. 5) with an RMSE $=$ $8.94 \mathrm{~m}$. Finally, it was found a difference of only $2.49 \mathrm{~m}$ for DEMs with lower and higher RMSE values, which reveals the consistency and stability of the Toutin's model.

\section{CONCLUSIONS}

The investigation supports the conclusion that for mountainous terrain in similar environments of the Brazilian Amazon, the ASTER altimetry fulfills the Brazilian Map Accuracy Standards elevation requirements for 1:100,000 A Class. In addition, since mountainous relief affects the performance of stereoscopic DEMs, it is expected better results with ASTER DEMs when dealing with flat terrains. It was possible to conclude that ASTER DEMs with RMSE errors less than 10 meters can be obtained with a few number of GCPs (minimum of 17), which is important considering the costs of GPS measurements for operational use in this kind of difficult terrain. Finally, it is important to mention that for cartographic production up-dated planimetric information is also necessary. Since ASTER also provides planimet- 
ric information, it can be a good alternative to overcome the critical lack of topographic information $(1: 100,000$ scale) in the Amazon Region.

\section{ACKNOWLEDGMENTS}

The authors would like to thank Dr. Robert N. Walker (Geoimage, Australia) for providing the ASTER stereopairs and to Conselho Nacional de Desenvolvimento Científico e Tecnológico (CNPq) for a grant received by the second author during this investigation (Process ref. no. 300985/90-8).

\section{RESUMO}

A Amazônia Brasileira é um rico e vasto território em recursos naturais renováveis e não-renováveis. Devido às condições ambientais adversas (chuvas, nuvens, vegetação densa) e difícil acesso, a informação topográfica ainda é escassa, e quando disponível necessita ser atualizada ou re-mapeada. Neste trabalho, a viabilidade de usar elevação para mapeamento topográfico por meio de imagens estereoscópicas orbitais ASTER foi investigada para relevo montanhoso na Serra dos Carajás, Pará. A qualidade da informação produzida destas imagens ópticas foi avaliada considerando medidas altimétricas de campo. Informações topográficas precisas de campo, adquiridas a partir do Sistema de Posicionamento Global (GPS), foram usadas como Pontos de Controle no Terreno (GCPs) para a modelagem de Modelos Digitais de Elevação (DEMs) estereoscópicos e como Pontos de Verificação Independentes (ICPs), para o cálculo das precisões em elevação. As análises foram realizadas seguindo duas abordagens: (1) a utilização do Erro Médio Quadrático (RMSE) e (2) cálculo das análises de tendência e precisão. A investigação mostrou que a acurácia altimétrica do ASTER atendeu aos requisitos altimétricos para a Classe A 1:100.000 do Padrão de Exatidão Cartográfico. Além disso, dados ASTER podem fornecer informação planimétrica atualizada que também é necessária para a produção cartográfica. Assim, quando as condições ambientais permitem a obtenção de estéreo-pares, o uso do imageamento ASTER pode ser considerado uma alternativa valiosa para mapeamento topográfico de semi-detalhe em ambientes similares da Amazônia Brasileira.

Palavras-chave: mapeamento topográfico, DEM, ASTER, estereoscopia, Região Amazônica.

\section{REFERENCES}

Camargo PO. 2003. Relatório do Processamento dos Dados GPS da Flona Tapajós. Projeto 99/06271-7 PIPEFAPESP, São José dos Campos, Technical Report, 56 p.

Cheng P AND MCBEAn L. 2002. Fly-through data generation of Afghanistan. Earth Observation Magazine (EOM) 11(1): 25-30.

Cheng P AND Toutin T. 1998. Unlocking the potential for IRS-1C data. Earth Observation Magazine (EOM) 7(3): 24-26.

Cuartero A, Felicisimo AM And Ariza FJ. 2005. Accuracy, reliability, and depuration of SPOT HRV and Terra ASTER digital elevation models. IEEE T Geosci and Remote Sens 43: 404-407.

Eckert S, Kellenberger T and Itten K. 2005. Accuracy assessment of automatically derived digital elevation models from ASTER data in mountainous terrain. Int $\mathrm{J}$ Remote Sens 26: 1943-1957.

ERSDAC. 2001. Earth Remote Sensing Data Analysis Center, ASTER user's guide part-I. General (Ver.3.1), Japan.

Fujisada H, Bailey GB, Kelly GG, Hara S AND ABRAMs MJ. 2005. ASTER DEM Performance. IEEE T Geosci and Remote Sens 43: 2707-2713.

Galo M and Camargo PO. 1994. O uso do GPS no controle de qualidade de cartas. In: CONGRESSO BRASileiro de CADAstro TÉCNico Multifinalitário (COBRAC-1994), 1, ANAIS. UFSC, Florianópolis, SC, Brasil.

Hirano A, Welch R and Lang H. 2003. Mapping from ASTER stereo image data: DEM validation and accuracy assessment. ISPRS J Photogram Eng Rem Sens 57: 356370.

Huggel C, Schneider D, Miranda PJ, Granados DD AND KÄÄB A. 2008. Evaluation of ASTER and SRTM DEM data for lahar modeling: A case study on lahars from Popocatepetl Volcano, Mexico. J Volcanol Geotherm Res 170: 99-110.

IBGE. 2001. Brazilian Institute of Geography and Statistics. Mapa Índice Digital - Mapeamento Geral do Brasil. $1^{\mathrm{a}}$ ed., CD-ROM.

KAMP U, Bolch T AND Olsenholler J. 2003. DEM Generation from ASTER Satellite Data for Geomorphometric Analysis of Cerro Sillajhuay, Chile/Bolivia. - ASPRS Annual Proceedings, 5, Anchorage, Alaska, USA, $9 \mathrm{p}$.

Merchant D. 1987. Spatial Accuracy Specification for Large Scale Topographic Maps. Technical Papers of the 
American Congress on Surveying and Mapping annual meeting, 42nd, Denver, CO, p. 222-231.

Paradella Wr, Oliveira CG, Cecarelli icF, COTTINI CP AND OKIDA R. 2005. Operational Use of RADARSAT-1 Fine Stereoscopy Integrated with TM-Landsat 5 Data for Cartographic Application in the Brazilian Amazon. Can J Remote Sens 31: 139-148.

PCI Geomatics. 2003. Geomatica OrthoEngine User Guide, version 9.0, Ontario, Richmond Hill, Canadá, $168 \mathrm{p}$.

SAN BT AND SÜZEN ML. 2005. Digital elevation model (DEM) generation and accuracy assessment from ASTER stereo data. Int J Remote Sens 26: 5013-5027.
Toutin T. 2002. Three-Dimensional Topographic Mapping with ASTER Stereo Data in Rugged Topography. IEEE T Geosci and Remote Sens 40: 2241-2247.

TOUTIN T. 2008. ASTER DEMs for geomatic and geoscientific applications: a review. Int J Remote Sens 29: 18551875.

Toutin T And Cheng P. 2001. DEM generation with ASTER stereo data. Earth Observation Magazine (EOM) 10(6): 10-13.

Wessels RL, KARgel JS AND KiefFer HH. 2002. ASTER measurement of supraglacial lakes in the Mount Everest region of the Himalaya. Annals of Glaciology 34: 399-408. 